could be their origin? And how far are they shown to other side of the stars so profusely scattered throughout be unalterable?

And, in the last place, what is the distance or real magnitude of that luminous mass? Is it on this or the the same visible area? It may be nearer, or, more correctly speaking, less unimaginably distant, than we are apt to suppose. It might even show sensible parallax, if

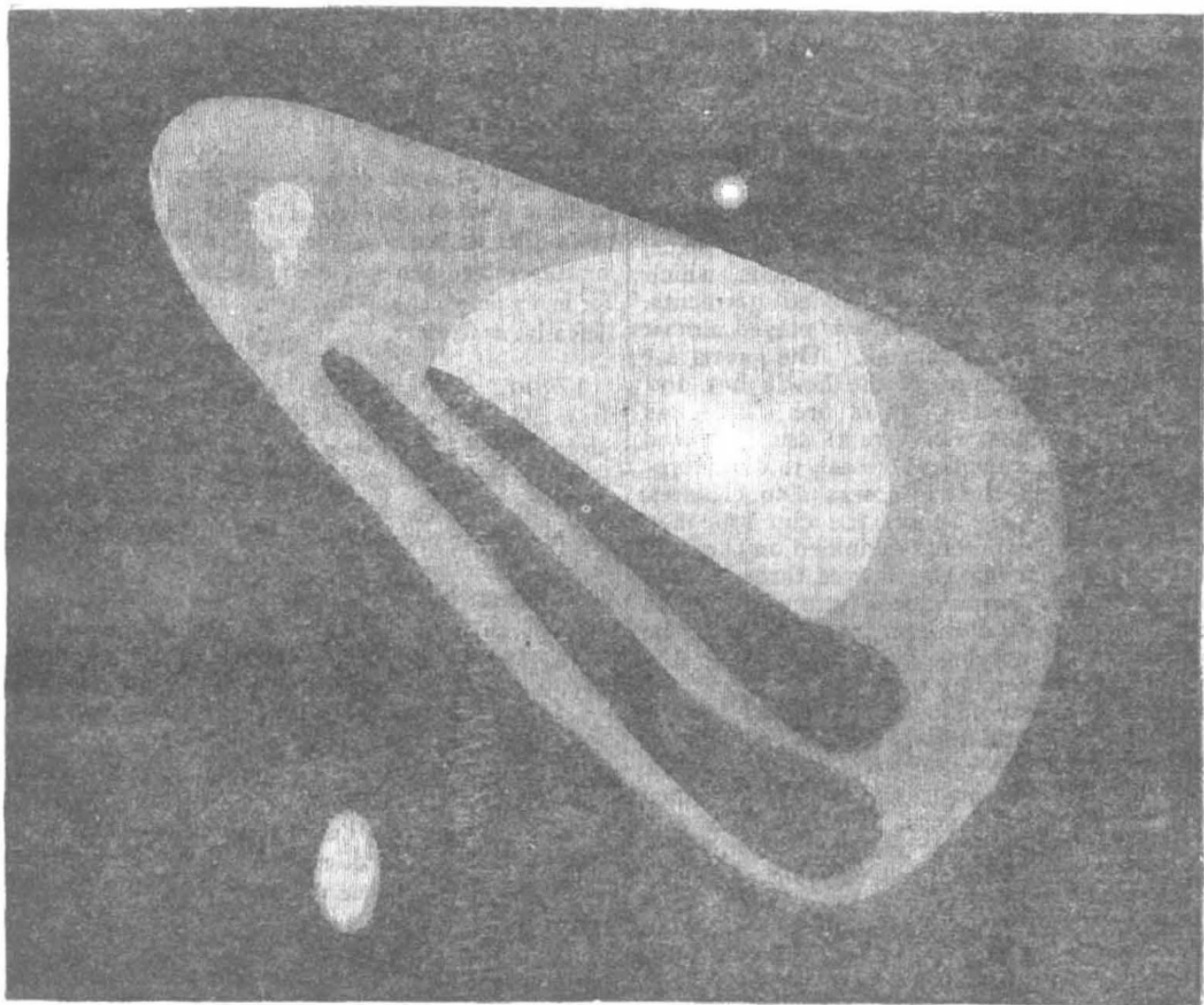

F1G. 3.-Perry, $\mathbf{1 8 8 \pi}$

d'Arrest's stellar point in II 7 could be compared in position with neighbouring stars; and even so, an enormous extent must still be assigned to it. Or it may lie yet further away in the unfathomable depths of space, expanded to a gigantic size-the largest body in the visible universe-the greatest display as to magnitude of its incomprehensible Creator.

And with these inquiries as to a mystery never in all probability to be penetrated by man, our imperfect remarks shall close.
T. W. WEBP

\section{A BEAR FESTIVAL AMONG THE AINOS}

A LTHOUGH it is well known that the Ainos of Yeso $A$ worship the bear, and have a festival known as the " bear-festival," at which that animal is killed, no foreign writer, except the one whom we are about to mention, has ever actually beheld this ceremony. Dr. Scheube, of Kioto, in a paper recently published in the Mittheilungen der deutschen Gesellschaft für Natur und Völker-kunde Ostasiens, describes one at wbich he was an honoured guest. He observes that these celebrations are becoming rarer every day; in the various villages which he visited there had not been one for some years. The motives assigned for this cessation of an old custom, is that the Ainos are becoming Japanised, and that the expenses are too great. In those parts of the island where Japanese habits have penetrated most, the absence of the skulls of the bears, which are also objects of veneration, is very ${ }_{4628} 6$ (Aquar Gaseous). The first of these I have seen well with my $9 \frac{1}{3}$-inch speculum. noticeable; and as the individual who gives a bear-feast is compelled to invite all his relations, friends, and neighbours, and to supply them with unlimited quantities of $s a k e$ (rice-beer)-a beverage which is three times mane expensive in Yeso than in Japan-the excuse on the score of expense is probably a valid one. It is, it. seems, incorrect to say that the Ainos reverence. the bear as they do their gods-the god of the fire or of the sea, for instance; but they respect the bear above all other animals. $\mathrm{He}$ is most useful to them; be supplies them with food, raiment, and even with medicine. On the other hand, when enraged, the bear is a terrar to them; he destroys their houses, plantations, and domestic animals, and kills themselves. The animal intended for sacrifice is selected while it is still very young, towards the end of winter, it is nourished by the wife of its owner at first, and when it gets stronger is fed on fish alone. In the beginning it runs freely about the house, but as it increases in size and strength it is placed in a cage. About September or October, when it is a 
year old, and has become so strong that it attempts to break its cage, the time for the ceremony is deemed to have come, and the great event of an Aino's life is about to take place. He first addresses long prayers to the gods and to the relations of the bear asking pardon for what he is about to do, and pleading that from the time the animal came into his possession he has showered favours on him, and has maintained him as long as possible; but he is poor, the bear is growing large, and he finds it impossible to support him any longer. He has therefore no resource but to slay him; and for this act, which is forced on him by inevitable necessity, he prays for forgiveness.

On arriving at the scene of the ceremony the visitor found about thirty persons, chiefly residents of the place, assembled, and dressed in their gala costumes, which consisted chiefly of old Japanese brocaded garments. From the commencement to the end saké played almost as prominent a part as the bear himself. The guests sat around the fire-place in the centre of the host's hut, and an offering was first made to the god of fire. This was done in this wise. The Ainos, who were all seated, raised their left hands, holding a drinking vessel, to their foreheads, while the palm of the right was also elevated slightly. A small stick lying across the cup was then dipped in the sake and the contents sprinkled on the floor to the fire-god, the stick being then waved three or four times over the cup. A formula was uttered by each person present, and the saké drank in long draughts, the stick being meanwhile employed in holding up the moustache. A similar ceremony then took place in front of the bear's cage. 'This was followed by a dance around the cage by the women and girls. Offerings of drink were then made as before to other gods, and finally the bear was taken out of his cage by three young men specially selected for the purpose. The animal was killed by pressing the throat firmly against a large block of wood. The body was then cleaned, and placed neatly on a mat, food and drink being laid before it, and ornaments of various kinds being placed on its ears, mouth, \&c. Mats were spread around the bear, the guests took their seats on them, and the drinking commenced. This continued for some time, until the Ainos sank in a state of helpless intoxication on their mats. The women in another part of the village meantime amused themselves with various dances, which Dr. Scheube describes at length.

The following day, as a rule, the debauch is continued. The body of the bear is then cut up in such a manner that the hide remains attached to the head. The blood was collected in vessels and drank by the men. The liver was cut out and eaten raw; the rest of the flesh was distributed amongst the partakers of the feast. The writer states that although hardened in a certain sense to the sight of blood, he could not look without horror on the sight of the drunken crowd with their faces and bodies smeared with blood. The skull of the bear-stuffed with charms - is placed in a sacred place on the east side of the house, and the mouth is filled with bamboo-leaves. It is then always preserved and venerated as a sacred object.

\section{NOTES}

Mr. WiLliam Bowman, LL.D., F.R.S., has been elected Honorary Secretary of the Royal Institution, and Dr. Warren De La Rue, F.R.S., Manager.

ON Monday the Royal Commissioners on Technical Education-Mr. B. Samuelson, M.P., Mr. Woodall, M.P., Prof. Roscoe, Mr. P. Magnus, Mr. Swire Smith, and Mr. Redgrave, secretary-visited Liverpool to inquire into technical science teaching. They met at the Free Library, and were furnished with information concerning its working by Sir James Picton. They afterwards visited several of the Board schools, and in the evening some of the science classes.

Dr. P. L. Sclater, the Secretary of the Zoological Society, will give the first of a course of four lectures on the Geographical Distribution of Animals, on Thursday next, Febraary I6, and Mr. W. Watkiss Lloyd the first of a course of four lectures on the Iliad and the Odyssey, on Saturday, February 18, at the Royal Institution.

AT the comparatively early age of fifty-two years Major Sir William Palliser, C.B., M.P., died very suddenly from heart disease on Saturday afternoon. Sir William Palliser was universally known through the projectiles that bear his name, and for many practical applications of science in both offensive and defensive armament.

KöNIG's great tonometer is, we observe, announced for sale. It would be a great pity if the opportunity of acquiring this magnificent and absolutely unique collection of standard tuningforks for the nation were thrown away. The collection was one of the finest things exhibited in Philadelphia, where it still lies, the project to purchase it for the University of Pennsylvania having fallen through. If it cannot be acquired for the national collection, of which a nucleus exists at South Kensington, surely it might be thought worth while to purchase it for either the Cavendish or the Clarendon Laboratory. But the nation that can give two thousand pounds for the plaster cast of the porch of a Spanish church can surely afford to buy the masterpiece of the master-maker of modern acoustical instruments, especially at the moderate price asked.

UPON the Island of Euboea fossil human remains are reported to have been recently discovered. The Greek Government has had the objects in question conveyed to Athens, where their scientific examination is now ordered.

The February number of the Deutsche Rundschau will contain an article by Prof. Häckel, of Jena, the celebrated evolutionist, on his scientific researches in India, where he has been travelling since last autumn and still is.

IMPORTANT steps have been taken towards the execution of the French Metropolitan Railway, the principal technical difficulty being the crossing of the Seine. The first line to be constructed will originate from St. Cloud, and have its terminus at Vincennes. Its underground run will begin at the rue de Rome; other stations will be at the Opera, Bourse, Arts-et-Métiers, Place de la République, and Place de la Bastille. The track from the Place de la République to the Place de la Bastille is not yet decided upon, owing to the difficulty of crossing the Canal St. Martin's. The work will commence with the opening of a new street in the most densely-crowded part of Central Paris.

A "Geographische Geselischaft" was founded last month in the University town of Jena, under the presidency of Dr. Schmid, one of the professors. Their Mittheilungen is to be a quarterly one, and is to chronicle the gecgraphical and ethnological researches of missionaries. The first part is to appear towards the end of March. These societies are springing up all over France so fast that their very names slip one's memory, but in this country we are still content with one, no more having been heard of the feeble attempt made to start a Commercial Geographical Society at Manchester.

From the Colonies and India we learn that valuable and important discoveries of copper and iron ore have been made at 